RESEARCH ARTICLE

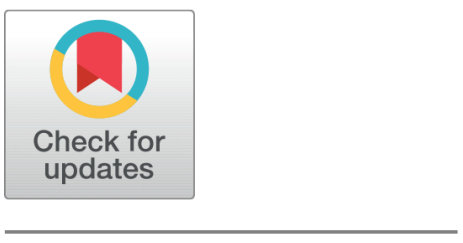

OPEN ACCESS

Received: 16.11.2020

Accepted: 05.01.2021

Published: 28.01.2021

Citation: Tahsildar N, Hasani R (2021) Faculty-perceived research skills and research productivity: A case study at a public University in Afghanistan. Indian Journal of Science and Technology 14(3): 229-238. https://doi.org/ 10.17485/IJST/v14i3.2065

* Corresponding author.

Tel: +6015543010323

nasim83.angel@gmail.com, tahsildar@hu.edu.af

Funding: None

Competing Interests: None

Copyright: (c) 2021 Tahsildar \& Hasani. This is an open access article distributed under the terms of the Creative Commons Attribution License, which permits unrestricted use, distribution, and reproduction in any medium, provided the original author and source are credited.

Published By Indian Society for Education and Environment (iSee)

ISSN

Print: 0974-6846

Electronic: 0974-5645

\section{Faculty-perceived research skills and research productivity: A case study at a public University in Afghanistan}

\author{
Nasim Tahsildar $^{1 *}$, Rahmatullah Hasani ${ }^{2}$ \\ 1 A PhD candidate at School of Education, Northeast Normal University (NENU), No.5268, \\ Renmin Street, Changchun, Jilin Province, P. R. China. Tel.: +6015543010323 \\ 2 Rahmatullah Hasani, a lecturer at Herat University (HU), No.3001, Danesh Street, Herat City, \\ Herat Province, Islamic Republic of Afghanistan
}

\section{Abstract}

Objectives: To investigate the faculty perceptions of their research skills, research productivity and related hindering factors at a public University in Afghanistan so as to help the Higher Education policy-makers make the required changes in their current decisions in terms of the quality of academic research in the country. Method: The study applied a mixed method approach within two phases: a quantitative phase, which tested the faculty perceptions of their research skills using a questionnaire and a qualitative phase, which examined the faculty insights on their research productivity as well as its determining factors. The study sample included 164 full time faculty members employed by the University. It started in July 2020 and ended at the beginning of December 2020. Findings: A new inventory was developed by the researcher to measure the faculty research skills. Findings based on this inventory indicated that faculty perceived to have mid level research skills with a low-level research productivity as evidenced by their research production. Three different types of hindering factors categorized as personal, institutional and management factors also appeared to be associated with the faculty research productivity. The study ends with specific suggestions to Afghan education policy-makers and faculty members so as to make the necessary changes and improvements in their policies with regard to research skills, research productivity and the determining factors. This study is the earliest study to investigate the faculty research skills and research productivity in Afghanistan university context.

Keywords: The faculty; research skills; research productivity; hindering factors

\section{Introduction}

Research is mainly done and disseminated by the faculty at universities through research productivity, which is measured in several ways including number of publications, citations, achievements in getting research funds, and worldwide ratings ${ }^{(1)}$. Research 
productivity is known as the main indicator of the universities' reputation and has been an important predictor of academic success in universities ${ }^{(2)}$. It is also the key element in providing the universities with different world ratings and rankings ${ }^{(3)}$. However, no university in Afghanistan is included in the major world ranking systems yet ${ }^{(4)}$. The main reason for this exclusion, as indicated by the literature, is lack of research productivity at universities. According to ${ }^{(5)}$, the university faculty in Afghanistan are experiencing a low level of research efficacy, which mainly comes from lack of enough research financial and professional supports $^{(6)}$. This low level of research efficacy at these institutions may also lead to low level of research productivity, which has not been investigated at any institutions in Afghanistan yet. Ministry of Higher Education in Afghanistan; however, has recently had more attention to the quality of research in universities and tried to support the faculty in conducting academic research in different disciplines ${ }^{(4)}$. There is agreement on improving the quality of teaching, research and public services in Afghanistan universities, but there is not specific agreement on how to measure the elements of these affairs at these universities ${ }^{(7)}$. So, measuring the current qualifications in terms of teaching and research through academic investigations can help Afghanistan higher education policy-makers plan the necessary requirements in a better way. Accordingly, the current study aims at investigating the faculty perceptions of their research skills and to determine how productive their research skills are. In addition, this study identifies the hindering factors impacting the faculty research productivity at a public University in Afghanistan.

In the recent literature, several personal and institutional factors such as the researcher's confidence ${ }^{(8,9)}$, collaborations ${ }^{(10)}$, trainings ${ }^{(11)}$, preference ${ }^{(12)}$, teaching load ${ }^{(13)}$, research skills ${ }^{(14)}$, institutional support ${ }^{(15)}$, degree ${ }^{(16)}$, facilities ${ }^{(17)}$, fund ${ }^{(18)}$, and job satisfaction ${ }^{(19)}$ have been confirmed to impact research productivity among the faculty at universities. However, findings on how many individual and institutional factors impact research productivity are not consistent ${ }^{(20)}$ and more research is required to lead to more consistent results among the faculty personal and institutional qualities and research productivity at universities ${ }^{(21)}$.

Among the factors, the faculty research skills are positively associated with their research productivity is ${ }^{(22)}$. This association implies that, as the faculty research skills increase, so does their research productivity and ultimately the faculty with more research skills are expected to be more productive compared with faculty who lack those skills. $\operatorname{In}^{(9)}$ also states that research productivity is influenced by the research skills through research competence. This is further supported by ${ }^{(23)}$, who significantly differentiate in research productivity between different areas of knowledge, not only through publications and citations but also through research productivity cycle. However, there is a dearth of evidence on the relationship between the faculty research skills and research productivity ${ }^{(24)}$. Different empirical studies have also been conducted to demonstrate factors which affect research skills and productivity at universities ${ }^{(25)}$; nevertheless, findings are not consistent and more studies are required to be conducted in this area ${ }^{(21)}$. Besides, the two constructs (research skills and research productivity) are integrated and investigated for the first time in Afghanistan university context.

There are different research productivity models in the literature. One of the famous models is developed by ${ }^{(25)}$. Bland's model is used to depict the faculty research productivity on two levels: the first level is on specific individual, institutional and leadership qualities related to the faculty research productivity. The second level is on a hierarchical order for the first level groups. At this level, the individual qualities are vital but this vitality depends on how encouraging the institution is in terms of research activities. Ultimately, the effect of the institution is facilitated by its leadership qualities and style ${ }^{(26)}$. This study followed Bland's model of research productivity with certain modifications, focusing on individual and institutional qualities of research productivity. This model can be supported by self-efficacy theory. The theory is developed by ${ }^{(27)}$, who defines selfefficacy as "confidence in one's capabilities to organize and execute the courses of action required to produce given attainments." Efficacy Theory also signifies the relationship between the academic staff's personal characteristics and capabilities with regards to their professional development ${ }^{(26)}$ and is closely related to performance of academic research productivity ${ }^{(28)}$.

Thus, although the literature implies that Afghanistan Higher Education Institutions continue to suffer a critical shortage in terms of teaching, research and public services, this shortage is recently addressed by the Ministry of Higher Education. As the ex-minister of Higher Education Balakarzai (2019) states, "The current number of higher education institutions is adequate. We should think about quality now." Therefore, identifying the current condition of research and research productivity can help the policy-makers make better decisions in terms of the faculty research skills and productivity. Accordingly, as a pioneer study, this research seeks to investigate the faculty research skills in four areas of understanding research basics, application of research methods, use of research technological tools and research writing. Research basics refer to the faculty abilities in choosing a research topic, searching the literature, and developing research questions, objectives and hypotheses. The second skill includes the faculty abilities to make use of different research methods such as qualitative, quantitative and mixed approaches. The next skill focuses on the faculty abilities to apply different technological tools to collect, analyze and manage their data. Ultimately, the faculty skill in research writing is investigated as the fourth skill. Consequently, the primary purpose of this study is to identify the level of the faculty research skills in the four mentioned areas using a quantitative approach and reveal the faculty research 
productivity and the contributing factors based on in-depth interviews with 12 faculty members from different disciplines. Accordingly, results of both quantitative and qualitative are used to explain the relationship between the faculty research skills and productivity.

\subsection{Research questions}

1. How do the faculty perceive their research skills in understanding about research basics, use of research methods, application of technological tools and research writing?

2. How productive are the faculty research skills at Herat University?

3. What are the main factors perceived to hinder the faculty research productivity?

\section{Materials and methods}

This study adopted a mixed method (the explanatory sequential mixed design) to gather and analyze the required data in two phases. The explanatory sequential mixed design is a two-phase approach, in which the researcher is interested to further explain about findings of the first phase of a study with the qualitative data collected in Phase $2^{(29)}$. So, in the first phase of this study, a questionnaire was used to test the faculty perceptions of their research skills while in the second phase in-depth interviews were conducted with 12 faculty members to further explain about the faculty research skills by examining the faculty insights on how productive their research skills were and what factors hindered their research productivity.

\subsection{Participants and sampling}

The participants in this study were 162 full time male and female faculty members officially employed at Herat University (HU). This sample covered 12 different colleges at HU, using the Proportionate Stratified Random Sampling Method. The strata in the current research are the 12 colleges. The reason behind this choice was that these colleges included the highest number of the faculty at the university. A total number of 200 questionnaires were distributed among the university faculty and only 160 were returned, from which 152 were used in this study. 12 more faculty members (one faculty from every college), who had already filled out the questionnaire, were also interviewed after the questionnaires were collected. These 12 faculty members were selected based on their English Language fluency by the help of an English Language Center (ELC), wherein the faculty from different colleges were studying English for Academic Purposes. Therefore, the total number of the participants were 164 faculty members from 12 different colleges of (1) Education, (2) Literature, (3) Sharia, (4) Agriculture, (5) Social Science, (6) Law, (7) Public Administration, (8) Journalism, (9) Economics, (10) Engineering, (11) Veterinary and (12) Medicine. More details on the demographic date are in Table 1.

Table 1. The participants' demographic data $(\mathrm{n}=152)$

\begin{tabular}{lllllllllllllll}
\hline Colleges & & 1 & 2 & 3 & 4 & 5 & 6 & 7 & 8 & 9 & 10 & 11 & 12 & Total \\
\hline \multirow{2}{*}{ Gender } & Male & 28 & 13 & 10 & 7 & 7 & 6 & 5 & 2 & 7 & 2 & 5 & 4 & 96 \\
& Female & 10 & 8 & 7 & 4 & 8 & 2 & 4 & 2 & 1 & 6 & 1 & 3 & 56 \\
\hline \multirow{2}{*}{ Education } & Bachelor & 10 & 8 & 5 & 2 & 8 & 2 & 2 & 1 & 1 & 3 & 2 & 2 & 46 \\
& $\mathrm{PhD}$ & 4 & 0 & 1 & 2 & 0 & 0 & 2 & 0 & 3 & 2 & 0 & 0 & 14 \\
\hline
\end{tabular}

\subsection{Measures}

The questionnaire used in this study was developed by the researcher, which investigated the faculty perceived research skill within four subscales of understanding research basics, application of research methods, use of research technological tools and research writing. It was a 10-point Likert scale (Appendix A) with 10 increments from 0 (not at all) to 9 (absolutely), including 24 items, with the holistic interpretation of high, middle, low and very low.

The research basics subscale was tested using 4 items, application of research methods with 9 items, use of research technological tools with 5 items and research writing with 6 items. The content validity was evaluated by two education professors with certain modifications recommended and the reliability was confirmed through a pilot study with some changes in the wording of the items and the instrument design. The internal consistency of the questionnaire in this study was found $\alpha$ $=0.949$, which indicates a high reliability. 
The interview questions in ${ }^{(26)}$ were adopted to collect data. In ${ }^{(26)}$, interview includes twenty open-ended questions which investigate individual and institutional factors in the forms of demographic, family-related and professional variables related to university research productivity ${ }^{(26)}$.

\section{Analysis}

\subsection{The quantitative phase}

Since the first main purposes of this study was to investigate the faculty perceptions of their research skills in understanding about research basics, use of research methods, application of technological tools and research writing, a descriptive analysis was applied to reveal the means and standard deviations of each of the four subscales in the questionnaire. Table 2 shows the summary of the descriptive statistics in this regard.

Table 2. Descriptive statistics of the faculty research skills $(n=152)$

\begin{tabular}{llllll}
\hline Variables & $\mathrm{N}$ & Min & Max & Mean & SD \\
\hline Research Basics & 152 & 2.75 & 9.00 & 7.172 & 1.419 \\
Research Methods & 152 & .56 & 8.78 & 6.106 & 1.640 \\
Technological Tools & 152 & .00 & 9.00 & 5.655 & 2.203 \\
Research Writing & 152 & 2.00 & 8.83 & 6.865 & 1.389 \\
Total & 152 & 1.79 & 8.88 & 6.380 & 1.486 \\
\hline
\end{tabular}

As indicated in Table 2, the faculty skills in understanding Research Basics ranges from 2.75 up to 9.00 with a mean of 7.172 $(\mathrm{SD}=1.419)$. The faculty skills in the application of Research Methods was found to range from .56 to 8.78 with a mean of $6.106(\mathrm{SD}=1.640)$. In addition, the faculty skills in use of Technological Tools ranged from .00 to 9.00 with a mean of 5.655 $(\mathrm{SD}=2.203)$. Moreover, the faculty Research Writing Skill ranging from 2.00 to 8.83 was found with a mean value of 6.865 $(\mathrm{SD}=1.389)$. On the other hand, the total mean value of the four subscales was reported $6.380(\mathrm{SD}=1.486)$. Thus, as per the descriptive statistics, the highest mean value of the faculty skills in understanding the Research Basics (7.172) indicates that the faculty were more skillful in this area than the other three research areas there. However, their skill in use of Technological Tools, which was reported with the lowest mean value of (5.655), reveals that the faculty experienced more difficulties in this area.

In order to compare the level of the faculty research skills based on colleges, a T-test was conducted to compare the means and standard deviations of the faculty research skills in the four areas at the 12 different colleges of HU. This comparison explores how the faculty in every college perceive their research skills. Result of every college is revealed in Table 3.

Table 3. The faculty research skills based on different colleges $(n=152)$

\begin{tabular}{|c|c|c|c|c|c|c|}
\hline Colleges & & Basics & Methods & Tools & Writing & Total \\
\hline \multirow{2}{*}{ Education } & Mean & 7.43 & 6.41 & 5.93 & 7.09 & 6.65 \\
\hline & $\mathrm{SD}$ & 1.13 & 1.68 & 2.27 & 1.43 & 1.55 \\
\hline \multirow{2}{*}{ Literature } & Mean & 7.45 & 6.51 & 6.16 & 7.27 & 6.78 \\
\hline & $\mathrm{SD}$ & 1.08 & 1.61 & 2.37 & 1.07 & 1.41 \\
\hline \multirow{2}{*}{ Sharia } & Mean & 6.70 & 5.66 & 5.43 & 6.47 & 5.99 \\
\hline & SD & 1.33 & 1.21 & 1.72 & 1.07 & 1.02 \\
\hline \multirow{2}{*}{ Agriculture } & Mean & 6.95 & 5.88 & 5.92 & 6.59 & 6.25 \\
\hline & $\mathrm{SD}$ & 1.61 & 1.50 & 1.75 & 1.21 & 1.27 \\
\hline \multirow{2}{*}{ Social Science } & Mean & 6.78 & 5.74 & 5.28 & 6.44 & 5.99 \\
\hline & $\mathrm{SD}$ & 1.63 & 1.73 & 2.33 & 1.62 & 1.53 \\
\hline \multirow{2}{*}{ Law } & Mean & 7.46 & 5.87 & 5.35 & 6.83 & 6.27 \\
\hline & SD & .73 & 1.62 & 2.37 & .71 & 1.23 \\
\hline \multirow{2}{*}{$\begin{array}{l}\text { Public } \\
\text { Administration }\end{array}$} & Mean & 7.27 & 6.07 & 5.53 & 6.90 & 6.37 \\
\hline & $\mathrm{SD}$ & 1.78 & 1.34 & 1.88 & 1.68 & 1.44 \\
\hline \multirow{2}{*}{ Journalism } & Mean & 7.37 & 6.94 & 6.00 & 7.08 & 6.85 \\
\hline & SD & 2.48 & 2.03 & 3.24 & 2.39 & 2.43 \\
\hline \multirow{2}{*}{ Economics } & Mean & 8.03 & 7.29 & 6.57 & 7.62 & 7.35 \\
\hline & $\mathrm{SD}$ & .95 & 1.30 & 2.17 & .95 & 1.20 \\
\hline
\end{tabular}

Continued on next page 


\begin{tabular}{lllllll}
\hline \multicolumn{2}{c}{ Table 3 continued } & & & & & \\
\hline \multirow{2}{*}{ Engineering } & Mean & 7.53 & 5.65 & 4.77 & 6.79 & 6.06 \\
& SD & 1.22 & 2.30 & 2.54 & 2.17 & 2.01 \\
\hline \multirow{2}{*}{ Medicine } & Mean & 5.78 & 4.79 & 3.94 & 6.28 & 5.15 \\
& SD & 2.12 & 1.40 & 1.92 & 1.32 & 1.44 \\
\hline \multirow{2}{*}{ Veterinary } & Mean & 6.54 & 5.66 & 5.50 & 6.22 & 5.91 \\
& SD & 1.70 & 1.54 & 2.34 & 1.15 & 1.41 \\
\hline \multirow{2}{*}{ Total } & Mean & 7.17 & 6.10 & 5.65 & 6.86 & 6.38 \\
& SD & 1.41 & 1.64 & 2.20 & 1.38 & 1.48 \\
\hline
\end{tabular}

As per Table 3, the faculty at the college of Economics were found to have the highest level of research skills with a mean value of (7.35) among the 12 colleges. Following that, colleges of Journalism with a mean value of (6.85), Literature (6.78), Education (6.65), Public Administration (6.37), Law (27), Agriculture (6.25), Engineering (6.06), Social Sciences (5.994), Sharia (5.990), Veterinary (5.91) and finally college of Medicine with mean of (5.15) were perceived to have the highest mean values, respectively. Another T-test was calculated to compare the faculty research skills in terms of their gender, age, degree, rank and experience. Details are as shown in Table 4.

Table 4. Research skills and demographics of the faculty members

\begin{tabular}{|c|c|c|c|c|c|}
\hline Categories & & $\mathrm{n}$ & $\%$ & Mean & SD \\
\hline \multirow{2}{*}{ Gender } & Male & 96 & 63.2 & 6.405 & 1.420 \\
\hline & Female & 56 & 36.8 & 6.337 & 1.604 \\
\hline \multirow{5}{*}{ Age } & $25-29$ & 50 & 32.9 & 5.615 & 1.603 \\
\hline & $30-34$ & 12 & 7.9 & 6.204 & 1.118 \\
\hline & $35-39$ & 45 & 29.6 & 6.447 & 1.430 \\
\hline & $40-44$ & 18 & 11.8 & 7.138 & .934 \\
\hline & $50-60$ & 20 & 13.2 & 7.179 & 1.118 \\
\hline \multirow{3}{*}{ Degree } & Bachelor & 46 & 30.3 & 5.518 & 1.738 \\
\hline & Master & 88 & 57.9 & 6.610 & 1.205 \\
\hline & $\mathrm{PhD}$ & 14 & 9.2 & 7.648 & .836 \\
\hline \multirow{5}{*}{ Rank } & Instructor & 78 & 51.3 & 6.281 & 1.546 \\
\hline & Lecturer & 49 & 32.2 & 6.708 & 1.296 \\
\hline & Assistant Prof & 20 & 13.2 & 6.060 & 1.579 \\
\hline & Associate Prof & 1 & 0.7 & 6.750 & 1.574 \\
\hline & Professor & 4 & 2.6 & 5.791 & 1.975 \\
\hline \multirow{6}{*}{ Experience } & $1-5$ & 51 & 33.6 & 5.785 & 1.623 \\
\hline & $6-10$ & 53 & 34.9 & 6.179 & 1.402 \\
\hline & $11-15$ & 23 & 15.1 & 7.469 & .779 \\
\hline & $16-20$ & 9 & 5.9 & 7.333 & .936 \\
\hline & $21-25$ & 6 & 3.9 & 7.208 & .766 \\
\hline & $26-30$ & 2 & 1.3 & 5.833 & 2.180 \\
\hline
\end{tabular}

As per Table 4, male faculty research skills were found to be higher with a mean value of (6.405) than their female counterparts with a mean value of (6.337). As for age, there seemed to a constant increase in the faculty research skills as they got elder. The mean value of research skills with the faculty between 25-29 was perceived (5.615) while this value seemed to constantly increase to (7.179) with the faculty between 50-60 years old. In terms of degree, the faculty with $\mathrm{PhD}$ degree scored higher than their master and bachelor colleagues with mean values of (7.648), (6.610) and (5.518), respectively. However, with reference to rank, Associate Professors perceived to have the highest research skills with a mean value of (6.750). Finally, with respect to teaching experience, the faculty members with 11-15 years of teaching experience showed to have a higher level of the highest level of research skill with a mean value of (7.469) while their counterparts between 26-30 years of teaching experience seemed to have the lowest research skills with a mean value of (5.833).

\subsection{The qualitative phase}

The second main purpose of this study was to examine the faculty insights on their research productivity and the factors hindering this productivity. All the 12 interviews which were audio-recorded, were transcribed and prepared for thematic analyses. Nvivo 12 was used to code the data. The outcome of the codes was signified as 3 main themes within 10 sub- 
themes which could explain the faculty research productivity and the main factors hindering the productivity. More details are demonstrated in Table 5.

Table 5. Themes associated with the faculty research productivity and research hindering factors

\begin{tabular}{lll}
\hline Variables & Themes & Sub-themes \\
\hline \multirow{2}{*}{ Research productivity } & Research output & $\begin{array}{l}\text { Local journals } \\
\text { International journals } \\
\text { Publication quality }\end{array}$ \\
\hline & & Gender \\
& Personal factors & Personal responsibilities \\
\cline { 2 - 3 } Hindering factors & Teaching hours \\
& & Variety of subjects taught \\
& & Workload \\
\cline { 2 - 3 } & Management factors & Lack of human sources \\
& & Lack of material sources \\
\hline
\end{tabular}

As per Table 5, the faculty perceptions of their research productivity were investigated through their research output published in local journals and international journals. The quality of the research output was also included as part the interview questions. The main interview question about the faculty research output in local journal was "How often do the faculty publish in local journals?" The faculty responses showed that there was only one local journal in the university (Andisha Journal), in which the faculty could publish quarterly. Many faculty members believed that it was not enough and sometimes they were waiting one year so as to get their articles published in this journal. For instance, one of the faculty (2) stated that "There is only one local journal publishing both natural and social sciences. It is not enough and we need wait sometimes around a year if we are supposed to publish. It does not publish English articles either." The main reason for the faculty publications in this journal was indicated as the faculty getting promotions. When the faculty were asked about the methods they used to conduct research, there was a general consensus that most of the articles in the local journal was based on library research and only few faculty members used experimental, quasi-experimental or survey research. For example, the faculty participant (5) in this regard said that "Previously we did just review research. Now we do almost different types but still majority is review research."

As for the faculty research output in international journals, there was a general consensus showing that based on the recent policies of the university, every faculty was supposed to get one or two articles (depending on the rank) published in international journals for getting an academic promotion. However, deficiency in the faculty familiarity to research methods and English language skills seemed to be the main challenges of getting published in international journals. For example, one of the many faculty participants (4) responded that, "Professors lack research skills to publish in international journals. We need more research trainings." The other faculty respondent (6) on the other hand added that "Some of the faculty do not know English language and it is why they cannot publish internationally."

When the faculty were asked about the quality of their publications, their responses implied that they could publish in any journal for their promotions. None of the 12 faculty who were interviewed had published in indexed journals such as Scopus and Web of Science. They believed that most of the faculty got their articles published in paid and low-quality journals. As a faculty (8) in this regard asserted, "I know very few who publish in high indexed journals but many faculties publish their articles in low quality paid journals." The faculty mean of the paid journals were the international journals without any peer reviews, which charge the researchers and publish their works regardless of the quality.

As per Table 5, factors hindering the faculty research productive were divided into three main themes of personal, institutional and management factors. Gender and personal responsibilities were perceived to be two hindering factors of the faculty research productivity. The main interview question asked to compare research productive among male and female faculty was "Who do you think is more productive? Male or female faculty?" The faculty responses implied that male faculty were more productive. The main reasons for this difference were assumed as family-related issues and social restrictions with female faculty members. For example, one of the respondents (10) asserted that, "Female faculty members have more responsibilities at home. They also should take care of their children and do the chores. It is why they can't do as much research as male faculty members." Another female faculty (7) confirming this, added that, "Female have problems collecting data from the society due to lots of social restrictions for them." On the other hand, personal responsibilities were perceived as the other hindering factors of research productivity. Many of the faculty believed that the faculty personal business specially their employment in private universities avoid them from conducting research. 
The next type of hindering factors was signified as institutional factors which included teaching hours, variety of subjects taught by the faculty and workload. The faculty responses about teaching hours showed that some of them taught around 25 hours per week and it was assumed as a hindering factor for conducting research. In addition, many of the faculty complained about the variety of subjects they were supposed to teach. Four of the faculty respondents $(1,6,9,11)$ claimed that they were teaching four different subjects, and they even did not have enough time to prepare for these subjects. Moreover, workload was brought up as a serious concern when the faculty were asked about the hindering factors. Almost all the faculty (10 out of 12) asserted that they were supposed to do lots of administrative affairs beside teaching. Getting involved in different working committee was another hindering factor that the faculty talked about. For instance, the faculty respondent (8) in this regard answered that, "I teach 25 classes with different subjects. I do lots of administrative works. I am also involved in different committees. So, I have no time to do research." On the other hand, another faculty (3) added that, "I teach four different subjects. I even don't have enough time to prepare for these subjects. I am also a member of four different committees."

Finally, when the faculty were asked about management factors, their responses implied that all of them perceived material and human sources as two types of management factors. Almost all the faculty agreed that they lacked enough material sources such as updated library, equipped labs, consistent internet, and monetary supports so as to manage their research projects. For example, one of the faculty respondents (9) expressed that, "Research trainings, time, facilities, labs are necessary to do quality research but we don't have enough of them." However, another faculty member (5) said that, "Although we have an almost good internet, there is no specific financial support." Other hindering factors were assumed as lack of research mentors, lack of enough motivation from the higher authorities, lack of specific research policies form the university, and the faculty problems in research skills specially in the methodology section.

\section{Discussion}

This mixed method study investigated the faculty perceptions of their research skills in four areas of understanding the research basics, using research methods, applying technological tools and research writing. In addition, it examined the faculty insights on how productive their research skills were and what factors hindered their research productivity. The descriptive analyses in this study revealed that the faculty felt more confident in their understanding of the research basics than the other three research areas. However, the faculty showed to feel the least confidence in terms of the application of the technological use. Following that, the faculty skills in research writing and using research methods were perceived to dominate each other, respectively. The faculty overall level of research skills was perceived to be at around 64\%, which is not that high. It is just above the midpoint. It indicates that the faculty are seriously in need of improving their research skills in different areas, especially in the application of technological use throughout their academic research activities. These results align with the qualitative findings of this study about the faculty insights with regard to their research productivity. In addition, similar findings were reported by ${ }^{(9,30)}$ with the faculty at a College of Dentistry having low level of research productivity investigated through their research output. However, in ${ }^{(30)}$, the faculty were found to feel the most confident with writing the technical part of the research and least confident with the methodology writing.

In the qualitative phase, this study examined the faculty insights on how productive their research skills were and what factors hindered their research productivity. The faculty research productivity was tested through the faculty research output in local and international journals and the quality of this output. Findings from the in-depth interviews with 12 faculty members implied that the faculty research output in terms of both quantity and quality was rather low. Their output in local journal was limited to almost one internal journal and their output in international journals was confined to certain low quality and paid international journals. Only few faculty members were reported to have published in indexed journals, from which none of the interview participants had any publications in journals indexed in SCOPUS, Web of Science or equivalent databases. Accordingly, these results imply that the faculty were low research productive and their research productivity was perceived to suffer not only in terms of quantity but in quality as well.

On the other hand, the faculty in their interviews pointed out to several hindering factors which stemmed from their personal, institutional and management factors. In terms of personal factors, the faculty believed that their gender as well as personal responsibilities out of the campus hindered their research productivity. Female faculty members were believed to be less productive due to household affairs and social restrictions. However, the male faculty members were perceived to have extra jobs beside their main jobs, which was thought to hinder their research productivity. As for institutional factors, majority of the faculty responses implied that teaching hours, variety of subjects taught by the same faculty member and administrative workload were the main causes of low research productivity. The faculty answers related to these factors showed that they desired to reduce their teaching hours, wanted to teach one or two specific subjects, and wished to increase their load of administrative works so as to attend research seminars and get much time to improve their research skills and productivity. In relation to the management factors, a significant number of the faculty agreed that lack of research experts and research facilities were two 
main research hindering factors in their colleges. All in all, compared with personal and management factors, the institutional factors in this study were perceived to affect the faculty research productivity these. These findings comply with results found by ${ }^{(2,6,13,15,20,31-34)}$; however, they contradict ${ }^{(21)}$ findings revealing that personal characteristics such as age, research competence and research skills affect the faculty research productivity more than management and institutional supports.

As per the demographic factors, findings showed that male faculty level of research skills was higher than the level of female faculty research skills. With respect to the faculty age, a constant increase was found in their research skills as they age. In terms of degree, the faculty with $\mathrm{PhD}$ degree scored higher than their master and bachelor colleagues, respectively. However, with reference to rank, Associate Professors perceived to have the highest research skills with a mean value of (6.750). Regarding the teaching experience, the faculty members with 11-15 years of teaching experience showed to have a highest level of research skills among all their counterparts. The demographic findings are consistent with the ones in ${ }^{(35)}$ and ${ }^{(36)}$ in terms of gender, and similar with results found by ${ }^{(37)}$ and ${ }^{(38)}$ as per the degree and rank and finally similar with ${ }^{(21)}$ findings in terms of teaching experience. However, findings related to the age of the faculty contradict ${ }^{(26)}$ study who concluded that age is a hindering factor and as the faculty get older, they are nearly at retiring, and seldom do research.

\section{Implications}

As per the interviews with 12 faculty members at Herat University, certain useful strategies can be used to develop the faculty research productivity at universities. First, the faculty should have less teaching load and the variety of subjects taught by the same faculty member should be decreased to one or two subjects. Secondly, administrative workload should also be decreased and the faculty involvement in different working committees should also be considered fairly. Moreover, since lack of enough research experts and research facilities were signified as two main causes of low research skills and productivity, both material and human sources should be provided for the faculty so as to improve their research skills as well as productivity through professional research training. Reinforcement training must be conducted by research experts and special attention in the training should be given to the faculty skills in the application of research methods and use of research technology to collect and analyze their data. The university stakeholders are also required to follow the faculty to apply their knowledge by providing more quality articles after they get trained. Further, the university should get the authorization of creating an international journal and encourage the faculty so as to get their works published both locally and internationally. Publications in higher ranked journals such as in Scopus and Web of Science must be highly encouraged and appreciated by the university stakeholders. The faculty academic English language skills should not be underestimated in this part. Finally, research funds especially for the bigger research projects should be among the university priorities.

\section{Conclusion}

This study is relevant to higher education administrators, policy-makers and faculty members. Policy makers and administrators can benefit from the findings to make the necessary changes and improvements in their policies. Findings of this study can help the faculty members to know the current status of their research skills and productivity and identify the related determining factors in this respect. In comparison to the previous study, the faculty research skills and productivity rates were lower. The hindering factors were also reported to seriously impact both research skills and productivity. Therefore, the higher education policy-makers and administrators are recommended to make concerted efforts to build the necessary improvements with regard to the faculty research policies and planning. More specifically, they have to think about the faculty teaching load and the variety of subjects taught by the same faculty member, seriously. In addition, they should avoid getting the faculty involved in so many working committees so that they can find enough time for doing research. Further, the university administrators also need to provide the faculty with enough research facilities and professional mentors and encourage them to participate in reinforcement research training. Finally, research funds, reward and punishment system, which can be the main motivating factors leading the faculty to produce more research, should not be ignored.

\section{Appendix}

\section{Appendix A: The questionnaire}

This questionnaire is to investigate your perceptions of your Research Skills. Please indicate how confident you feel in each of the questions by giving accurate answers to the scale below. Determine the amount of confidence about each item with a number between ( 0 ) and (9). 0 indicates uncertainty (not at all) and 9 indicates your complete confidence (absolutely). 


\begin{tabular}{|c|c|c|}
\hline No & I am able to: & Number (1-9) \\
\hline 1 & Choose a proper research topic & \\
\hline 2 & Search for different scientific sources & \\
\hline 3 & Determine and define the variables & \\
\hline 4 & Develop research objectives, questions and hypotheses & \\
\hline 5 & Choose a proper method (quantitative/qualitative) for my research & \\
\hline 6 & Design a qualitative approach (e.g. ethnography) & \\
\hline 7 & Design a quantitative approach (e.g. case study) & \\
\hline 8 & Determine the sample using sampling method & \\
\hline 9 & Collect data using recent methods and approaches & \\
\hline 10 & Work with quantitative and qualitative data & \\
\hline 11 & Do different statistical analyses & \\
\hline 12 & Develop a reliable research tool & \\
\hline 13 & Understand validity and reliability concepts & \\
\hline 14 & Use technological tools such SPSS, STATA etc & \\
\hline 15 & Use different data collection tools & \\
\hline 16 & Use tests such ANOVA and T-test & \\
\hline 17 & Use reference tools such as End Note, Mendeley etc. & \\
\hline 18 & Know advanced statistics test such as Correlation and Regression & \\
\hline 19 & Write an Introduction and a Problem Statement & \\
\hline 20 & Write an analytic Literature Review & \\
\hline 21 & Write the Method sections of the research & \\
\hline 22 & Write the Discussion and Conclusion sections & \\
\hline 23 & Write the References in different styles & \\
\hline 24 & Write the outputs of the statistical analyses & \\
\hline
\end{tabular}

\section{References}

1) Feldman KA. Research productivity and scholarly accomplishment of college teachers as related to their instructional effectiveness: A review and exploration. Res High Educ. 1987;26:227-298. Available from: https://doi.org/10.1007/BF00992241.

2) Alghanim SA, Alhamali RM. Research productivity among faculty members at medical and health schools in Saudi Arabia: Prevalence, obstacles, and associated factors. Saudi Med J. 2011. Available from: https://pubmed.ncbi.nlm.nih.gov/22159387/.

3) Henry C, Ghani NAM, Hamid UMA, Bakar AN. Factors contributing towards research productivity in higher education. International Journal of Evaluation and Research in Education (IJERE). 2020;9(1). Available from: https://dx.doi.org/10.11591/ijere.v9i1.20420.

4) Welch A, Wahidyar A. Quality assurance in Afghan higher education: achievements and challenges. Asian Education and Development Studies. 2019;9(4):479-493. Available from: https://dx.doi.org/10.1108/aeds-09-2018-0146.

5) Tahsildar N. Afghanistan efl teacher preparation institutions and efl teaching efficacy in public schools. 2019. Available from: https://doi.org/10.30762/ jeels.v6il.1144.

6) Tahsildar N, Kabiri A. The relationship between af ghanistan efl students' academic self-efficacy and english language speaking anxiety. Acad J Educ Sci. 2019;p. 190-202. Available from: https://doi.org/10.31805/acjes.636591.

7) Ju SH, Kuo HH, Ni SH. Vibration Induced by Moving Cranes in High-Tech Buildings due to Rail Pad Materials. Shock and Vibration. 2018;2018:1-9. Available from: https://dx.doi.org/10.1155/2018/8623913.

8) Mcgrail MR, Rickard CM, Jones R. Publish or perish: a systematic review of interventions to increase academic publication rates. 2006. Available from: https://doi.org/10.1080/07294360500453053.

9) Wichian N, Wongwanich S, Bowarnkitiwong S, S. Factors affecting research productivity of faculty members in government universities: LISREL and Neural Network analyses. Kasetsart J - Soc Sci. 2009. Available from: https://www.researchgate.net/publication/.

10) Shin JC, Cummings WK. Multilevel analysis of academic publishing across disciplines: research preference, collaboration, and time on research. Scientometrics. 2010;85(2):581-594. Available from: https://dx.doi.org/10.1007/s11192-010-0236-2.

11) Ahmad AR, Farley A, Soon NK. Impact of the government funding reforms on the research and development at Malaysian public universities. Asian Social Science. 2014. Available from: https://doi.org/10.5539/ass.v10n14p13.

12) Mamiseishvili K, Rosser V. Examining the Relationship between Faculty Productivity and Job Satisfaction. J Profr. 2011. Available from: https: //www.jstor.orglchar"203A|relaxstable.

13) Jung J. Faculty Research Productivity in Hong Kong across Academic Discipline. 2012. Available from: https://doi.org/10.5539/hes.v2n4p1.

14) Sulo T, Kendagor R, Kosgei D. Factors affecting research productivity in public universities of Kenya: the case of Moi University, Eldoret. Emerg Trends Econ Manag Sci. 2012. Available from: https://www.semanticscholar.org/paper/Factors-Affecting-Research-Productivity-in-Public-Sulo-Kendagor/ 1e458dc33146cedb0841aa86767103cf9997de44. 
15) Hoffmann K, Berg S, Koufogiannakis D. Success in Research: Factors that Contribute to Increased Research Productivity Across Librarianship and Other Disciplines. Proceedings of the Annual Conference of CAIS / Actes du congrès annuel de l'ACSI. 2016. Available from: https://dx.doi.org/10.29173/cais852.

16) Quimbo MAT, Sulabo EC. Research productivity and its policy implications in higher education institutions. 2014. Available from: https://doi.org/10. 1080/03075079.2013.818639.

17) Ghabban F, Selamat A, Ibrahim R, et al. The influence of personal and organizational factors on researchers' attitudes towards sustainable research productivity in Saudi universities. 2019. Available from: https://doi.org/10.3390/su11174804.

18) Nafukho FM, Wekullo CS, Muyia MH. Examining research productivity of faculty in selected leading public universities in Kenya. International Journal of Educational Development. 2019;66:44-51. Available from: https://dx.doi.org/10.1016/j.ijedudev.2019.01.005.

19) Jameel AS, Ahmad AR. Factors Impacting Research Productivity of Academic Staff at the Iraqi Higher Education system Article View project leadership capability team leaders in construction industry in Malaysia View project. 2020. Available from: https://www.researchgate.net/publication/341930816.

20) Oyama Y, Fukahori H, Miyashita M, Narama M, Kono A, Atogami F, et al. Cross-sectional online survey of research productivity in young Japanese nursing faculty. Japan Journal of Nursing Science. 2015;12(3):198-207. Available from: https://dx.doi.org/10.1111/jjns.12060.

21) Alhija F, and AM. Predictors of Teacher Educators' Research Productivity. Australian Journal of Teacher Education. 2017;42(11):34-51. Available from: https://dx.doi.org/10.14221/ajte.2017v42n11.3.

22) Kahn JH. Predicting the scholarly activity of counseling psychology students: A refinement and extension. Journal of Counseling Psychology. 2001;48(3):344-354. Available from: https://dx.doi.org/10.1037/0022-0167.48.3.344.

23) Gonzalez-Brambila C, Veloso FM. The determinants of research output and impact: A study of Mexican researchers. 2007. Available from: https: //doi.org/10.1016/j.respol.2007.03.005.

24) Pasupathy R, Siwatu KO. An investigation of research self-efficacy beliefs and research productivity among faculty members at an emerging research university in the USA. Higher Education Research \& Development. 2014;33(4):728-741. Available from: https://dx.doi.org/10.1080/07294360.2013.863843.

25) Bland CJ, Center BA, Finstad DA, Risbey KR, Staples JG. A Theoretical, Practical, Predictive Model of Faculty and Department Research Productivity. Academic Medicine. 2005;80(3):225-237. Available from: https://dx.doi.org/10.1097/00001888-200503000-00006.

26) Lertputtarak S. An Investigation of Factors Related to Research Productivity in a Public University in Thailand : A Case Study. 2008. Available from: http://citeseerx.ist.psu.edu/viewdoc/download?doi=10.1.1.667.4673\&rep=rep1\&type=pdf.

27) Bandura A. Self-Efficay: The Excercise of Control. Springer Ref. 1987. Available from: https://www.amazon.fr/Self-Efficacy-Exercise-Control-AlbertBandura/dp/0716728508.

28) Tosi HL, Locke EA, Latham GP. A Theory of Goal Setting and Task Performance. 1991. Available from: https://doi.org/10.2307/258875.

29) Creswell JW. Steps in Conducting a Scholarly Mixed Methods Study. DBER Speaker Series. 2013. Available from: https://digitalcommons.unl.edu/cgi/ viewcontent.cgi?article $=1047 \&$ context=dberspeakers.

30) Jr BEB, Clerigo MEC. Factors Associated with Research Productivity among Oral Healthcare Educators in an Asian University. International Education Studies. 2013;6(8):124-135. Available from: https://dx.doi.org/10.5539/ies.v6n8p124.

31) Iqbal MZ, Mahmood A. A. Factors related to low research productivity at higher education level. Asian Soc Sci. 2011;7:188-191. Available from: https://doi.org/10.5539/ass.v7n2p188.

32) Webber K. Measuring faculty productivity. 2012. Available from: https://doi.org/10.1007/978-94-007-1116-7_6.

33) Shariatmadari M. Barriers to research productivity in Islamic Azad University: exploring faculty members perception. Indian Journal of Science and Technology. 2012;5(5):1-5. Available from: https://dx.doi.org/10.17485/ijst/2012/v5i5.12.

34) Ha C, Press M. Developing Faculty Research Skills: Lessons Learned. Community College Journal of Research and Practice. 2019;43(6):431-440. Available from: https://dx.doi.org/10.1080/10668926.2018.1490218.

35) Eloy JA, Svider PF, Cherla DV, et al. Gender disparities in research productivity among 9952 academic physicians. 2013. Available from: https: //doi.org/10.1002/lary.24039.

36) Nygaard LP. Publishing and perishing: an academic literacies framework for investigating research productivity. 2017. Available from: https://doi.org/10. 1080/03075079.2015.1058351.

37) D’Amico R, Vermigli P, Canetto SS. Publication productivity and career advancement by female and male psychology faculty: The case of Italy. Journal of Diversity in Higher Education. 2011;4(3):175-184. Available from: https://dx.doi.org/10.1037/a0022570.

38) Hesli VL, Lee JM. Faculty Research Productivity: Why Do Some of Our Colleagues Publish More than Others? PS: Political Science \& Politics. 2011;44(02):393-408. Available from: https://dx.doi.org/10.1017/s1049096511000242. 